\title{
FROM SHAREHOLDER RIGHTS TO SHAREHOLDER DUTIES - A TRANSFORMATION OF EU CORPORATE GOVERNANCE IN A SUSTAINABLE DIRECTION?
}

\author{
Hanne S. Birkmose *
}

\begin{abstract}
Corporate governance discussions in Europe on shareholders' rights have increasingly been replaced by discussions on shareholders' duties. This trend is reflected in company and capital markets law, where shareholders increasingly are imposed duties towards investee companies. For example, the legalization of shareholders' duties was a key element in the EU Commission's amendment to the Shareholder Rights Directive in 2017 (Directive 2017/828). A key to this transformation is shareholder accountability, in particular in relation the share ownership of institutional investors. Thus, the transformation bodes a break with an embedded perception according to which the relationship between shareholders and the investee company reflects a private ordering at the center of the European corporate governance model. The increased focus on shareholder accountability emphasizes the societal aspect of share ownership and, more generally, the interest that society holds in public limited liability companies. On the basis of a discussion of the amended Shareholder Rights Directive and the possible implications of this transformation, the paper concludes is that it is questionable whether shareholders can serve as a reliable vehicle for transformation of company law towards a more sustainable framework.
\end{abstract}

KEYWORDS: Shareholder rights, shareholder duties, Shareholder Rights Directive, corporate governance, EU company law, enforcement, sustainability, sustainable growth, principal-agency theory, externalities

\footnotetext{
Professor at Department of Law, Aarhus BSS, Aarhus University, Denmark; hsb@law.au.dk
} 


\section{INTRODUCTION}

Corporate governance discussions in Europe on shareholder rights have increasingly been replaced by discussions of shareholder duties. ${ }^{1}$ This trend is reflected in company law and capital markets law, where shareholders increasingly are imposed duties towards investee companies, other shareholders and market participants. Previous research has analyzed a variety of duties imposed on shareholders. ${ }^{2}$ These duties show great variety as well as variance across Member States in the EU. The discussion of shareholder duties gained momentum after the financial crisis, and questions related to appropriate roles for shareholders in internal corporate governance received special scrutiny. The EU corporate governance framework has at all times emphasized the importance of shareholder engagement, and previous legislative initiatives have strengthened shareholder rights in order to spur shareholder involvement in corporate governance. However, weaknesses in the EU corporate governance framework became evident during the financial crisis, ${ }^{3}$ and European as well as national legislators faced pressure to react to the financial markets' collapse.

Consequently, not only were the discussions about shareholder rights in corporate governance gradually supplemented with discussions about shareholder duties, but legislative action also reinforced shareholder duties in corporate governance through new provisions in company law. Probably the most prominent example of such shareholder oriented post-crisis regulation is the EU Commission's amendment to the Shareholder Rights Directive (SRD II), which was adopted in 2017 (Directive 2017/828), and shareholder duties was a novel element. This marks a break with the traditional perception in company law that shareholders have no duties when they invest in companies. Moreover, it also bodes a break with an embedded perception according to which the relationship between shareholders and the investee company is a private ordering. The provisions on shareholder engagement found in SRD II suggest

\footnotetext{
Shareholder duties is the topic of a research project based at Aarhus University from 20142018. This research project received financial support from the Danish Council for Independent Research. The author would like to thank the Council for their financial support. The work on this paper is also carried out as part of the research project 'Social Interest and Corporate Governance Balance: Shareholders' Duties and Managers' Duties', which is supported by the Spanish Ministry of Economy, Industry and Competitiveness.

2 For a mapping of these duties, see Birkmose, H. S. and Möslein, F.: Introduction: Mapping shareholders' duties, in: Birkmose, H. S. (ed.): Shareholders' Duties, Alphen aan den Rijn, 2017, pp. 1-25.

3 See Corporate Governance in Financial Institutions and Remuneration Policies, Green Paper, (COM(2010) 284 final), and EU Corporate Governance Framework, Green Paper, (COM(2011) 164 final).
} 
that shareholders should be accountable to other company constituents when exercising their shareholder rights, thus emphasizing a societal aspect of share ownership that previously has not been dominant.

Therefore, SRD II can be seen as an indication of a transformation of company law. Status quo is not considered an option in a post-crisis perspective, and a transformation is needed to set a new direction for corporate governance practices. A transformation of company law involves an extensive and radical change that orients companies and their shareholders in a new direction.

One of the overarching objectives of SRD II is to contribute to the long-term sustainability of EU companies. ${ }^{4}$ Sustainable development has become an integrated aim of the accomplishment of the internal market. ${ }^{5}$ In relation to the Commission's Action Plan on Financing of Sustainable Growth, sustainable finance concerns 'improving the contribution of finance to sustainable and inclusive growth by funding society's long-term needs, and strengthening financial stability by incorporating environmental, social and governance (ESG) factors into investment decision-making. ${ }^{6}$ Even though SRD II does not define sustainability, the documents that preceded the Directive highlight the emphasis on short-term gains by some companies and shareholders as incompatible with sustainable development. ${ }^{7}$ In relation to this article, it is sufficient to understand sustainability as a broad term that encompasses three dimensions, each of which is important to a company's activities: economic development, social development and environmental protection. Providing incentives for companies to take these dimensions seriously will also intensify their focus on long-term company practices, which is considered an inherent part of sustainability.

\footnotetext{
4 Proposal for a Directive amending Directive 2007/36/EC as regards the encouragement of long term shareholder engagement and Directive 2013/34/EU as regards certain elements of the corporate governance statement (COM(2014) 213 final), Section 1.

5 See for example the preamble of the consolidated version of the Treaty on European Union ('TEU'), 2016/C 202/01, Communication From the Commission, Europe 2020, A strategy for smart, sustainable and inclusive growth, $\operatorname{COM}(2010) 2020$ final and Communication From The Commission to The European Parliament, The European Council, The Council, The European Central Bank, The European Economic and Social Committee and The Committee of The Regions. Action Plan: Financing Sustainable Growth, COM(2018) 97 final.

6 Communication From The Commission to The European Parliament, The European Council, The Council, The European Central Bank, The European Economic and Social Committee and The Committee of The Regions. Action Plan: Financing Sustainable Growth, p. 1, $\operatorname{COM}(2018) 97$ final.

7 E.g. the 2010 Green Paper, Section 3.5 and the 2011 Green Paper, introduction and Sections 1.4 and 2.2.
} 
The purpose of this article is to assess the extent to which shareholder duties can be an effective vehicle to ensure sustainable, long-term oriented corporate governance. In short, I am skeptical about the ability of SRD II, on its own, to provide sufficient momentum and for shareholder duties in general to be an appropriate vehicle for a transformation of corporate governance that is politically driven from above.

The article begins with a discussion of shareholder duties in Section 2, and explains why shareholders have become the center of regulatory attention even though shareholders are just one interest group among many in a company's sphere. Moreover, this section focuses on situations where we could expect duties to be imposed on shareholders. The rights shareholders are given in company law are closely integrated with the corporate governance duties we find in both company and capital market law. Section 2.1 explores this connection and unfolds some the most important governance duties. The amended Shareholder Rights Directive takes corporate governance duties to a new level, and the emerging engagement duties found in the directive are discussed in Section 3 in order to determine not only the content of the duties, but also their aim. The latter is important because the aim seems to go beyond the prevalent understanding of appropriate shareholder monitoring in corporate governance, which raises the question of whether SRD II requirements are likely to compel shareholders to embrace a more prominent role in corporate governance and, if so, if we can expect that role be used to promote a more sustainable, long-term corporate agenda. This discussion, the focus of Section 4, concludes that is questionable whether SRD II will be sufficient to induce the institutional investors to make significant changes to their engagement practices. Consequently, the effects realized may depend on how efficiently the provisions are enforced, and Section 5 takes up this important question. Finally, I sum up the discussions in Section 6 and point to some of the questions that legislators need to consider if shareholder duties are to become a reliable vehicle for transformation of corporate governance towards a more sustainable framework. Section 7 concludes.

\section{WHY SHAREHOLDERS?}

Shareholders, creditors and employees all have an intense and focused interest in corporate behavior. However, EU legislation has mandated the performance of specific, politically-oriented functions by shareholders and shareholders alone, and not by the other groups. It is therefore relevant to start out by considering, why shareholders have become the center of attention.

The simple answer is that shareholders have a unique position in company law and in corporate governance. Contrary to other groups of company constitu- 
ents, company law across Member States grants shareholders a number of fundamental rights that are exclusive to this group. ${ }^{8}$ Notable among these are the right to receive a dividend, the right to the return of surplus capital on winding up the company, and the right to vote at the general meeting. ${ }^{9}$ Other rights include the right to speak at the general meeting, to table resolutions and to call an extraordinary meeting. These rights are protected by company law and resemble proprietary rights to some extent, ${ }^{10}$ even though shareholders do not own the company or the company assets, but only the shares of the company. ${ }^{11}$

While share ownership carries certain rights, the general perception has been that share ownership, in itself, does not entail any duties for shareholders. Nor do we find that the proprietary rights derived from share ownership entail any duties in general. ${ }^{12}$ Moreover, shareholders have been considered to be free to choose whether or not to exercise the rights they have been given, ${ }^{13}$ and they are not obliged to do so. ${ }^{14}$

8 Pennington, R.: Company Law, London, 2001, pp. 160-1; Worthington, S.: Shares and Shareholders: Property, Power and Entitlement: Part 1, Company Lawyer, 22(9) 2001, p. 260 f.; Davies, P. L.: Gower's Principles of Modern Company Law, London, 2001, pp. 817 ff.; and Ireland, P.: Company Law and the Myth of Shareholder Ownership, Modern Law Review, 62(1) 1999, p. $46 \mathrm{f}$.

9 Bird, H.: A Critique of the Proprietary Nature of Share Rights in Australian Public Listed Corporations, Melbourne University Law Review, 22, 1998, p. 137.

10 Chiu, I. H.-Y.: The Meaning of Share Ownership and The Governance Role of Shareholder Activism in The United Kingdom, Richmond Journal of Global Law \& Business, vol. 8, 2008-2009, pp. $121 \mathrm{ff}$.

11 Worthington, S.: Shares and Shareholders op cit note 8, p. 259; Demsetz, H.: Toward a Theory of Property Rights, American Economic Review 57(2) 1967, p. 359; Stein, P \& Shand, J.: Legal Values in Western Society, New York, 1974, p. 220; Ireland, P.: Company Law op. cit. note 8.; Davies, P.L.: Gower's Principles op. cit. note 8, p. 815, which refers to Short v. Treasury Commissioners (1948) 1 K.B. 122, C.A.; and Deakin, S.: The Corporation as Commons: Rethinking Property Rights, Governance and Sustainability in the Business Enterprise, Queen's Law Journal, vol. 37, 2012, p. 355 f..

12 Birkmose, H. S.: Forcing Shareholder Engagement: Theoretical Underpinning and Political Ambitions, European Business Law Review, 29(4) 2018, p. 633.

13 See among others Barker, R. M. \& Chiu, I. H.-Y.: Corporate Governance and Investment Management, London, 2017, p. 165; and Birkmose, H. S.: European Challenges for Institutional Investor Engagement - is mandatory disclosure the way forward? European Company and Finance Law Review, vol. 11 2014, pp. 225 ff.

14 See Sørensen, K.E.: Duty of loyalty for shareholders - a possible remedy for conflicts in SME's, in: Neville, M. \& Sørensen, K. E. (eds.), Company Law and SMEs, Copenhagen, 2009, pp. $128 \mathrm{ff}$. However, some jurisdictions may impose a fiduciary duty on shareholders, see Cahn, A.: The Shareholders' Fiduciary Duty in German Company Law, in: Birkmose, H. S.: (ed.), Shareholders' Duties, Chapter 16. 
Shareholder rights were at the core of the 2007 Shareholder Rights Directive. ${ }^{15}$ The purpose of this directive was to enhance shareholder rights in listed companies, to facilitate and encourage shareholder engagement and to solve problems related to cross-border voting. ${ }^{16}$

The rights granted to shareholders in company law, and emphasized with the adoption of the Shareholder Rights Directive, are fundamental to the European corporate governance model. The Commission has increasingly emphasized the role of shareholders in corporate governance. In the 2012 Action Plan, the Commission stated that 'effective, sustainable shareholder engagement is one of the cornerstones of listed companies' corporate governance model'. ${ }^{17}$ The Commission has also stated that the corporate governance framework is 'built on the assumption that shareholders engage with companies and hold the management to account for its performance ${ }^{18}$ and that shareholders have a crucial role to play in promoting better governance of companies. By doing this they act in both the interest of the company and their own interest. ${ }^{\prime 19}$ Consequently, by monitoring corporate decisions, shareholders play an important role in the checks and balances of company management. However, to understand the role of shareholders in corporate governance, we must look not only to company law, but also to the economic theories behind the European corporate governance framework - and in particular at the agency relationship between the shareholders and the board of directors. ${ }^{20}$

In a corporate governance perspective, principal-agent theory most commonly focuses on the relationship between the information-rich board of directors (the agent) and the company's shareholders (the principal), whose interests the board ostensibly serve. ${ }^{21}$ Here, shareholder rights are important as part of a

15 Directive 2007/36/EC of the European Parliament and of the Council of 11 July 2007 on the exercise of certain rights of shareholders in listed companies.

16 See Recitals 1 and 3, Directive 2007/36/EC.

17 European Company Law and Corporate Governance - A modern legal framework for more engaged shareholders and sustainable companies, (COM(2012) 740 final), section 3.

18 The EU Corporate Governance Framework, Green Paper, (COM(2011) 164 final), introductory remarks.

19 European Company Law and Corporate Governance - A modern legal framework for more engaged shareholders and sustainable companies, (COM(2012) 740 final), section 1.

20 See in particular Jensen, M. C. \& Meckling, W. H.: Theory of the Firm: Managerial Behavior, Agency Costs and Ownership Structure, Journal of Financial Economics 3(4) 1976; Fama, E. \& Jensen, M.: Separation of Ownership and Control, Journal of Law and Economics 26 (2) 1983.

21 Armour, J., Hansmann, H., \& Kraakman, R.: Agency Problems and Legal Strategies, in: Kraakman, R. et al. (eds.), The Anatomy of Corporate Law. A Comparative and Functional 
legal governance strategy to enable the principal to control the agent's behavior. ${ }^{22}$ By contrast, in an agency relationship, duties are primarily relevant to legal regulatory strategies that aim to constrain the agent in ways that ensure protection of the interests of the principal. In the agency relationship between the shareholders and the board of directors, the shareholder is the principal. Consequently, agency theory explains the focus on shareholder rights in corporate governance, but it does not explain why duties are imposed on the shareholders, as they are the principals. However, shareholders can be understood as the principals in two other relationships: ${ }^{23}$ those with company customers, creditors and employees and, importantly, with other shareholders. ${ }^{24}$

In all agency relationships, information asymmetries may lead to suboptimal outcomes, and disclosure can be an important means to offset an agent's potential information advantage. This is discussed further in Section 2.1, below. However, asymmetric information and conflicts of interest not only occur among company constituents. Such conflicts of interest, so-called externalities, sometimes rise between the company and non-contractual parties. ${ }^{25}$ Shareholder duties may also be imposed to address externalities in situations where shareholders are in a position to cause market failure, as for example when they engage in market activities on the basis of private information

To sum up, shareholders have become the center of attention partly because of their unique position in company law and in internal corporate governance, due to the control rights they are granted in company law. Still, even though corporate governance theory stresses the importance of shareholder monitoring, the economic theories on which the corporate governance framework is built do not support the notion that shareholders have duties related to the companies in which they invest. ${ }^{26}$ Nonetheless, if we look to other important

\footnotetext{
Approach, Oxford, 2017, p. 29 f., where three different agency problems in a company are defined.

22 For a discussion on 'regulatory strategies' in relation to agency relationships, see Armour, J., Hansmann, H., \& Kraakman, R.: Agency Problems, op. cit. note 21, pp. 31 ff. See also Birkmose, H. S.: Duties Imposed on Specific Shareholders Only, and Enforcement Implications, in: Birkmose, H. S. \& Sergakis, K. (eds.): Enforcing Shareholders' Duties, London, 2018, (forthcoming).

23 Armour, J., Hansmann, H., \& Kraakman, R.: Agency Problems, op. cit. note 21, p. 30.

24 See Birkmose, H. S.: Duties Imposed on Specific Shareholders, op. cit. note 22, p. (forthcoming).

25 Externalities describe the cost or benefit that affects a party who did not choose to incur that cost or benefit. This might be the result of a market failure. See Armour, J., Hansmann, H., \& Kraakman, R.: Agency Problems, op. cit. note 21, p. 30.

26 Birkmose, H. S.: Forcing Shareholder Engagement, op. cit. note 12, pp. 616ff.
} 
agency relationships in companies, where shareholders act as the agents of other company constituents, we can understand that shareholder duties might be best understood as being part of a legal strategy to deal with conflicts of interest and asymmetric information. Such an explanation, however, sidesteps the question of why SRD II has a particular focus on the duties of a specific subset of shareholders: institutional investors. ${ }^{27}$ This puzzle is discussed in Section 3.

\subsection{CORPORATE GOVERNANCE DUTIES}

As discussed above, the European corporate governance model emphasizes the involvement of shareholders in the checks and balances of the board of directors. Here asymmetric information is an inherent problem because the board of directors may have an information advantage. But it is also possible that the majority shareholder, who might wish to influence the company, has an information advantage over minority shareholders. As discussed above, a legal strategy for controlling agency costs is to facilitate the principal's control over their agents' behavior. ${ }^{28}$ The efficacy of such a strategy depends highly on the ability of the principal to exercise its control rights. In this respect, disclosure duties imposed on the agent are an important auxiliary mechanism, as it evens out the information advantage the agent may have and it allows the principal to assess the actions of the agent. ${ }^{29}$ Thus, disclosure duties are also an important auxiliary mechanism to the governance strategies pursued by company law in which shareholder rights are at the core.$^{30}$ Outside the inherent agency relationships in companies, asymmetric information may be problematic in relation to externalities, which is why informing the market and market participants via mandated disclosures could be a key to ensuring an efficient capital market. ${ }^{31}$

Consequently, disclosure duties are found in company law as well as in capital market law. While it may not be surprising that corporate governance duties are found in company law, as ensuring good corporate governance is an essential part of the company law framework, it may be more surprising that corporate governance related duties are also found in capital market law.

\footnotetext{
27 In broad terms, the provisions in SRD II only apply to undertakings carrying out activities of life assurance or institutions for occupational retirement provision and asset managers. See SRD II, Article 2.

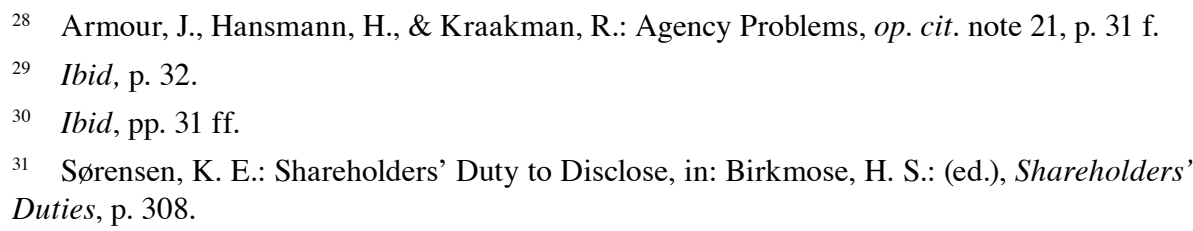


Company law is intended to reduce the costs of transactions that take place within a business form with certain characteristics rather than within a market per se. ${ }^{32}$ Organizing a business through the corporate form, involves a risk that company constituents ${ }^{33}$ - including shareholders, the board of directors, creditors and employees - engage in opportunistic behavior, or that conflicts of interest occur. Therefore, the regulatory framework seeks to constrain value-reducing forms of opportunism and to control conflicts of interest.

The aims of capital market law are different from those of company law. The contractual relationship between market participants is of less importance here, as a primary aim is to ensure the existence of efficient capital markets. Moreover, capital market law also serves an important public interest function, in the sense that the state has a clear interest in the well-being of capital markets, an interest that goes beyond advancing the private interests of individual market participants. Thus, protecting against market failures, including those caused by asymmetric information, is a main focus in capital market law. However, the disclosure rules found in capital market law go beyond market efficiency; a number of these duties are also intended to enhance good corporate governance. ${ }^{34}$

The corporate governance duties found in the law serve several purposes, with most falling into one of two categories of disclosure duties. ${ }^{35}$ They serve either to provide information about ownership or control structures of a company, or to ensure transparency about a shareholder's intentions. That is, the law seeks to make transparent the ways influence has been or will be exercised.

Because corporate governance duties aim to promote better corporate governance, most disclosure duties only apply to specific shareholders or groups of shareholders who have the potential to exercise significant (negative) influence on a company. For example, shareholders often must disclose holdings of a certain size, or certain defined relationships to the company, e.g. if the shareholder is also a director. ${ }^{36}$ This is consistent with the discussion above, as these shareholders either have a majority holding (and thus act as agents of the minority), or may be able to cause a market failure due to the information their position in the company may provide access to.

While corporate governance issues concern all limited liability companies, some of the duties apply only to shareholders in listed companies. This is un-

32 See Armour, J. et al., 'What Is Corporate Law?', in: Kraakman, R. et al. (eds.), The Anatomy, op. cit. note 21 , p. $1 \mathrm{f}$...

33 Ibid.p. 2 f.

34 For a thorough discussion, see Sørensen, K. E.: Shareholders' Duty to Disclose, op. cit. note 31 , p. 311-20.

35 Sørensen, K. E.: Shareholders' Duty to Disclose, op. cit. note 31, pp. 311-20.

36 See Birkmose, H. S.: Duties Imposed on Specific Shareholders, op. cit. note 22, (forthcoming). 
surprising with regard to duties found in capital market law, but shareholders in listed companies are also subjected to duties in company law, in particular those found in SRD II. ${ }^{37}$ While listed companies are more likely to have cross-border elements and therefore are more prone to EU regulation, also in the area of company law, it is more surprising that these duties apply only to some institutional investors, a scope that hardly can be explained by agency theory or fears of market failure. ${ }^{38}$

\section{SHAREHOLDER ENGAGEMENT}

The shareholder engagement provisions in SRD II take corporate governance a step further than previous attempts to encourage shareholders to take a more proactive role in investee companies. The question of appropriate shareholder engagement, an emerging corporate governance discussion, takes its starting point in the rights granted to holders of shares in limited liability companies. These control and governance rights are an inherent part of share ownership, as discussed above. ${ }^{39}$ The EU Commission has for years emphasized the importance of shareholder rights, and the adoption of the Shareholder Rights Directive $^{40}$ in 2007 was an important measure to strengthen the rights of shareholders across Member States.

The strengthening of shareholders rights is important for shareholders who want to engage in the governance of investee companies. Traditionally, the corporate governance agenda has been regarded as optional for shareholders, and shareholders had been free to choose to exercise their given rights or to remain passive. However, a new agenda is emerging, whereby the traditional engagement agenda that relies primarily on shareholder rights is coupled with disclosure duties for institutional investors and asset managers that aim to increase long-term, sustainable shareholder engagement. This new agenda has materialized with SRD II, which was adopted in $2017 .{ }^{41}$

\footnotetext{
37 In broad terms, the provisions in SRD II only apply to undertakings carrying out activities of life assurance or institutions for occupational retirement provision and asset managers. See SRD II, Article 2.

38 See Birkmose, H. S.: Duties Imposed on Specific Shareholders, op. cit. note 22, (forthcoming).

39 'What Is Corporate Law?' in: Kraakman, R. et al. (eds.), The Anatomy, op. cit. note 21, pp. $11 \mathrm{ff}$.

40 Directive 2007/36/EC of the European Parliament and of the Council of 11 July 2007 on the exercise of certain rights of shareholders in listed companies.

41 Directive (EU) 2017/828 of the European Parliament and of the Council of 17 May 2017 amending Directive 2007/36/EC as regards the encouragement of long-term shareholder engagement.
} 


\subsection{THE SHAREHOLDER RIGHTS DIRECTIVE}

The amended Shareholder Rights Directive was born in the aftermath of the 2008 financial crisis, when national and supranational regulators were under pressure to react to the malpractices of market participants, including the shareholders, after the financial markets' collapse. In the 2010 and 2011 Green Papers, the EU Commission stressed that the lack of shareholder engagement might have contributed to the extensive consequences of the crisis. ${ }^{42}$ Trust in shareholders had been shaken during the financial crisis, and the Commission argued that the observed passivity of shareholders raised 'questions about the effectiveness of corporate governance rules based on the presumption of effective control by shareholders. ${ }^{43}$ Still, despite this criticism of a system that relied on the idea that a shareholder would engage and hold management to account for its performance, the Commission continued to rely on shareholder engagement as 'one of the cornerstones of listed companies' corporate governance model' ${ }^{44}$ Thus, the Commission stated in its 2012 Action Plan that it would propose an initiative on the disclosure of institutional investors' voting and engagement policies as well as their voting records, all in an effort to improve transparency on investor practices and improve corporate governance in listed companies ${ }^{45}$ The Commission put forward a proposal for an amendment of the Shareholder Rights Directive in April $2014^{46}$ and, after some adjustments during the negotiations in the European Parliament, the SRD II was adopted three years later, in April 2017.

The SRD II includes a Chapter $1 \mathrm{~b}$ on the transparency required of institutional investors, asset managers and proxy advisors. Of particular interest in this chapter is Article 3g, titled 'Engagement Policy'. Paragraph 1 states:

Member States shall ensure that institutional investors and asset managers either comply with the requirements set out in points (a) and (b) or publicly disclose a clear and reasoned explanation why they have chosen not to comply with one or more of those requirements.

42 See Corporate Governance in Financial Institutions and Remuneration Policies, (COM(2010) 284 final), section 3.5 (hereinafter the '2010 Green Paper'); and The EU corporate governance framework $(\mathrm{COM}(2011) 164$ final), section 2 (hereinafter the '2011 Green Paper').

43 The 2010 Green Paper, section 3.5.

44 The 2012 Action Plan (COM(2012) 740 final), section 3.

45 See the 2012 Action Plan (COM(2012) 740 final), section 2.4.

46 Proposal for a Directive of the European Parliament and of the Council amending Directive 2007/36/EC as regards the encouragement of long-term shareholder engagement and Directive 2013/34/EU as regards certain elements of the corporate governance statement. COM(2014) 213 final. 
Typesetter: please indent the following two quoted paragraphs, so that they are shown clearly as sub-paragraphs to the quoted paragraph immediately above

(a) Institutional investors and asset managers shall develop and publicly disclose an engagement policy that describes how they integrate shareholder engagement in their investment strategy. The policy shall describe how they monitor investee companies on relevant matters, including strategy, financial and non-financial performance and risk, capital structure, social and environmental impact and corporate governance, conduct dialogues with investee companies, exercise voting rights and other rights attached to shares, cooperate with other shareholders, communicate with relevant stakeholders of the investee companies and manage actual and potential conflicts of interests in relation to their engagement.

(b) Institutional investors and asset managers shall, on an annual basis, publicly disclose how their engagement policy has been implemented, including a general description of voting behavior, an explanation of the most significant votes and the use of the services of proxy advisors. They shall publicly disclose how they have cast votes in the general meetings of companies in which they hold shares. Such disclosure may exclude votes that are insignificant due to the subject matter of the vote or the size of the holding in the company.

\subsection{AIM OF THE DIRECTIVE}

From the text it is clear that the primary aim of Article $3 g$ is to ensure public disclosure of institutional investors' and asset managers' investment strategies, their engagement policy and the implementation thereof. ${ }^{47}$ Alternatively, institutional investors and asset managers may disclose an explanation as to why they have chosen not comply with the provisions (comply or explain). Engagement with investee companies is part of a legal governance strategy under which shareholders actively assert their control over the board of directors. However, as discussed above in Section 2, we would not expect any duties to be imposed on the shareholders in their role as principal vis-à-vis the board of directors, as governance strategies aim to facilitate the principal's ability to control the agent's behavior. It is thus more reasonable to understand disclosure duties like those found in Article 3g as mechanisms to assist efforts by an institutional investor's own principals to control their agent - the institutional

See also Barker, R. M. \& Chiu, I. H.-Y.: Corporate Governance and Investment Management, London, 2017, p. 182 f. 
investor. Nothing in SRD II challenges this interpretation. However, a closer look at the preamble of the SRD II suggests that the aim goes beyond enhancing corporate governance as traditionally understood. Recital 16 states that

.... Public disclosure of such information could have a positive impact on investor awareness, enable ultimate beneficiaries such as future pensioners to optimize investment decisions, facilitate the dialogue between companies and their shareholders, encourage shareholder engagement and strengthen their accountability to stakeholders and to civil society.

Arguably, the purpose is not fully clear from the wording of this recital. From a corporate governance perspective, all shareholders have a financial interest in monitoring the board. However, the SRD II limits the disclosure duties to institutional investors and asset managers. ${ }^{48}$ An argument that supports this emphasis on institutional investors and asset managers is that this type of shareholder has a long-term commitment to its own principals: their beneficiaries. ${ }^{49}$ Since these beneficiaries, for example investors in pension schemes, are interested in the size of their return many years down the road, they expect their fund managers, for example pension fund managers, to use their shareholder power to encourage a similarly long-term focus by investee companies. Disclosure by the institutional investors would be consistent with a governance strategy that enables the principal (the beneficiaries) to control their agent (the institutional investor). While institutional investors undoubtedly are agents of their beneficiaries, this agency relationship has usually not been regulated in company law, though.

In addition to protecting the interests of these beneficiaries, the disclosure of the information in Article $3 \mathrm{~g}$ seems to aim at ensuring the interests of a number of other company interest groups, including other investors and the investee companies themselves. If an institutional investor is the majority shareholder, then its actions can affect the interests of minority shareholders. But if such minority interests should be protected, then surely they should be protected with reference to all majority shareholders and not only institutional investors. Further, this argument does not take into consideration the range in size and investment strategies among members of the institutional investor 'group'. While it can be argued that duties should be imposed on institutional investors when they are in a position to cause market failure due to asymmetric

\footnotetext{
48 Moreover, only a subset of the institutional investor population is covered by the provisions in Chapter 1b, supra n. 27.

49 EU Corporate Governance Framework, Green Paper, (COM(2011) 164 final), section 2.1. See also Fairfax, L. M.: Making the Corporation Safe for Shareholder Democracy, Ohio State law Journal, vol. 69 2008, p. 83.
} 
information, it can hardly be argued that institutional investors per se can be expected to be a unique cause of market failure.

While the disclosure duties in Article $3 \mathrm{~g}$ cannot be seen strictly as an engagement duty, due to the flexible 'comply or explain' approach, the article contains some very detailed expectations for institutional investors' engagement with investee companies. These duties may be seen as implicit engagement duties. ${ }^{50}$ Engagement expectations, built seem to go beyond the monitoring of the boards, which traditionally underlies the agency relationship between shareholders and the board of directors. This relationship builds on the premise that shareholders have a financial incentive to monitor the boards of directors to ensure that the value of their investment is maximized. ${ }^{51}$ Emphasizing an expectation for institutional investors to include in their engagement policy how they monitor investee companies on issues such as 'strategy, financial and non-financial performance and risk, capital structure, social and environmental impact and corporate governance' and how they 'communicate with relevant stakeholders of the investee companies' suggests that institutional investors are expected to include interests that go beyond their own private interest. Looking at Recital 16 again, it mentions that disclosure of the required information should 'strengthen their accountability to stakeholders and to civil society.' It is not quite clear who 'their' refers to. However, in the 2012 Action Plan an almost identical wording is seen in Section 2.4. Here it is said that disclosure 'could strengthen companies' accountability to civil society. ${ }^{52}$ This might even suggest that institutional investors should be watchdogs on behalf of civil society's interests in listed companies. ${ }^{53}$ Undoubtedly, civil society has an interest in the financial well-being of companies, but the extent of accountability owed by shareholders to civil society is arguable even after implantation of SDR II. The traditional division of power in limited liability companies limits the shareholders' role to controlling the board and leaves the board of directors as responsible for ensuring compliance of its company with any duties associated with the service of broader public interests. In addition,

50 See also Chiu, I. H.-Y. \& Katelouzou, D., who in their paper, From Shareholder Stewardship to Shareholder Duties: Is the Time Ripe? argue that the SRD II is a tentative step towards a hardening of engagement duties. In: Birkmose, H. S.: (ed.), Shareholders' Duties, § 7.04.

51 See among others Fama, E. \& Jensen, M.: Separation of Ownership and Control, op. cit. note 20; Jensen, M. C. \& Meckling, W. H.: Theory of the Firm, op. cit. note 20.

52 European Company Law and Corporate Governance - A modern legal framework for more engaged shareholders and sustainable companies, (COM(2012) 740 final).

53 The trend where the impact of listed companies on society and the overall economy becomes the focus of increased public attention has been labelled 'publicness'. See Fisch, J. E., The Mess at Morgan: Risk, Incentives and Shareholder Empowerment, University of Cincinnati Law Review, vol., 83, 2014, p. 653 with further references. 
while institutional investors traditionally have been accountable to their beneficiaries, SDR II's provisions seem to hold this sub-group of investors accountable to a wider range of stakeholders, including society. Moreover, post-SRD II disclosure provides stakeholders with information, which they might use to hold institutions accountable.

This line of reasoning leads directly to the argument that the amendment to the Shareholder Rights Directive takes a stronger stand on the obligation of at least a subset of the institutional investor population to become more actively involved in corporate governance. The Directive has introduced a new type of shareholder duty. This duty falls outside the framework by which we are able to explain most shareholder duties in company law or capital market law, as discussed above in Section 2. ${ }^{54}$ Rather, it could be argued that these duties are motivated by a post-crisis political agenda that includes increased transparency between companies and investors, increased shareholder engagement to improve corporate governance practices and an increased focus on sustainability and long-term commitment. Institutional investors have been identified as a group whose self-interest aligns closely with the latter two goals. ${ }^{55}$ Compared with other investor groups, institutional investors are most likely to have engagement policies that further the political agenda that is embedded in SRD II. Nonetheless, as the discussion below suggests, much stands between an emerging engagement duty as specified in SDR II and a transformation of corporate governance.

\section{ENGAGEMENT DUTIES - WHAT SHOULD WE EXPECT FROM INSTITUTIONAL INVESTORS?}

It is hard to predict the effect of SRD II requirements on either institutional investors or the companies in which they invest. As discussed in Section 2, principal-agent theory predicts that duties will be imposed on shareholders either to constrain their behavior or to enable other company constituents to control shareholders who are the agents of these constituents. However, SRD II duties do not aim to constrain the behavior of institutional investors in specific ways, but rather to change their general behavior. As discussed in the previous section, the aim is somewhat unclear and the provisions in Article $3 \mathrm{~g}$ do not specify clearly what the expectations are. Still, it is clear that the overall aim is to institutional investors, further in their engagement with investee companies

\footnotetext{
54 See Birkmose, H. S.: Duties Imposed on Specific Shareholders, op. cit. note 22, (forthcoming).

55 See the 2011 Green Paper, $(\operatorname{COM}(2011) 164$ final) section 2.1.
} 
in order to improve corporate governance practices. ${ }^{56}$ This new approach allows us to consider the potential of shareholder duties to serve as a driver for a transformation of corporate governance in a more sustainable direction. Such a transformation, including corporate service of public interests, seems not to be far from the aim of the directive.

But what can we expect from shareholders, and especially from institutional investors? Are they going to embrace this more prominent role in corporate governance? Historically, shareholder engagement has been rather low in most Member States, which helps to explain why the Commission has taken a new approach with SRD II. ${ }^{57}$

The Commission has pointed out different reasons for the lack of engagement in the Green Papers preceding the Directive, such as conflicts of interest, costs of engagement and lack of sufficient shareholder rights. ${ }^{58}$ While each of these may contribute to a better understanding of past engagement levels, part of the reason may also be that the general position in company law is that institutional investors have a duty of loyalty only towards their beneficiaries, and even the extent of even this is debated. ${ }^{59}$ Traditionally, it seems, the European stand has been that this fiduciary duty does not oblige institutional investors to engage with investee companies. ${ }^{60}$

Without a duty to engage or a duty of loyalty, shareholders could be expected first and foremost to use the rights they are given to protect their private interests in the company. Share ownership is very often an investment, and shareholders can be expected to engage to protect the value of this investment. Even though other private interests, including social or public objectives, may

56 This is also found in relation to the development of the UK stewardship code, see Jennifer G. Hill, Images of the shareholder - shareholder power and shareholder powerlessness, in Hill, J. G. \& Thomas, R. S. (eds.): Research Handbook on Shareholder Power, London, 2015, p. 65 f.

57 See the 2010 Green Paper, $(\operatorname{COM}(2010) 284$ final), section 3.5, and the 2011 Green Paper, (COM(2011) 164 final) section 2.1. See also SRD II, recital 2.

58 In particular, the 2010 Green Paper, (COM(2010) 284 final), section 3.5.

59 See the contributions to Hawley, J. P. et.al (eds.): Cambridge Handbook of Institutional Investment and Fiduciary Duty, 2014.

60 See among others Barker, R. M. \& Chiu, I. H.-Y.: Corporate Governance and Investment Management, London, 2017, pp. 63 ff. and 163 f. and Birkmose, H. S.: European Challenges op. cit. note 13, pp. $229 \mathrm{ff}$. However, the duty to vote is understood to be a fiduciary duty owed by some institutional investors to their beneficiaries in the US. See Employee Retirement Income Security Act of 1974, 29 US Code Chapter 18, Sections 1101-14. See also See also Rock, E. B.: Institutional Investors in Corporate Governance, in Gordon, J. N. \& Ringe, W.-G.: The Oxford Handbook of Corporate Law and Governance, 2018, p. $375 \mathrm{ff}$. and Youngdahl, J.: The basis of fiduciary duty in investment in the United States, in Hawley, J. P. et.al (eds.): Cambridge Handbook of Institutional Investment and Fiduciary Duty, 2014, p. 22 ff. 
exist ${ }^{61}$ the predominant theories expect financial interests to prevail. Therefore, without legislation or other institutional incentives, we can expect shareholders to act as drivers for transformation only to the extent that doing so will protect their financial interest in the company. Moreover, whether or not shareholders will remain passive or engage will partly depend on a cost benefit analysis, and the extent of engagement can be expected to correlate with its expected impact on the return on investment. ${ }^{62}$ The costs are primarily the cost of engagement, ${ }^{63}$ and the expected benefits will primarily occur in the form of increased company value as reflected in the share price.

SRD II expects institutional investors to make use of the rights they are granted by company law to ensure better corporate governance - not just to further their own interests in the company, but to further the interests of non-shareholder groups as well. That is, SRD II intends to use institutional investors as a vehicle to promote corporate action on issues that are of concern to the wider public. ${ }^{64}$ Even if we assume that SRD II provides shareholders with sufficient incentives to engage, however, the presumption that their interests are aligned with the interests of other stakeholders or society might not survive a closer inspection. This is why shareholders in general may be imperfect agents for other company constituents or the general public. ${ }^{65}$ Moreover, because shareholders are able to diversify their investments, they may be more risk tolerant than other company constituents. ${ }^{66}$ Finally, it is not at all clear that institutional

${ }_{61}$ Fairfax, L. M.: Making the Corporation Safe for Shareholder Democracy, op. cit. note 49, p. $82-85$.

62 Daniëlle Melis, Leen Paape \& Mijntje Lückerath-Rovers warn against loading institutional investors with too many burdens in Enforceability of institutional investors' responsibilities in corporate governance through the Dutch Corporate Governance Code: are regulators and practitioners on the same page (and to who are institutional investors accountable)? Working Paper 2017, p. 22, at https://papers.ssrn.com/sol3/papers.cfm?abstract_id=1975763. See also Rock, E. B.: Institutional Investors in Corporate Governance, in Gordon, J. N. \& Ringe, W.-G.: The Oxford Handbook of Corporate Law and Governance, 2018, p. $373 \mathrm{f}$.

63 See Birkmose, H. S.: The transformation of passive institutional investors to active owners - mission impossible? in: Birkmose, H. S.: et al. (eds.), The European Financial Market in Transition, 2011, pp. $117 \mathrm{ff}$.

64 See also Fisch, J. E., The Mess at Morgan, op. cit. note 53, pp. 665 ff. See for a UK perspective Barker, R. M. \& Chiu, I. H.-Y.: Corporate Governance and Investment Management, London, 2017, p $123 \mathrm{ff}$.

65 Fisch, J. E., The Mess at Morgan, op. cit. note 53, p. 668. See also Gerald Hertig, who argues in: Governance by Institutional Investors in a Stakeholder World' that, of different groups of institutional investors, the interests of pension fund might be the closest to 'ordinary' other stakeholders' interests, in: Gordon, J. N. \& Ringe, W-G: The Oxford Handbook of Corporate Law and Governance, Oxford, 2018, p. 836.

66 Fisch, J. E., The Mess at Morgan, op. cit. note 53, p. 668. 
investors have the capacity to serve wider purposes: shareholdings in hundreds or even thousands of companies dilute their interest in any single company; they may lack sufficient information to monitor for example the social and environmental impact of their companies; and they may lack the resources needed to gain such information, much less to include such factors meaningfully in their decision making. That is not to say, though, that shareholder interests are opposed to those of non-shareholders: if shareholders are too narrowly interested in short-term profit maximization and neglect a company's social responsibility, it might negatively affect the cost of capital and, consequently, the value of the company. ${ }^{67}$

It is therefore questionable whether the duties imposed by SRD II will be sufficient to induce institutional investors to make significant changes to their engagement practices, and even more questionable whether institutional investors will embrace a more prominent in role that includes non-shareholder interests. ${ }^{68}$ All of this said that the impact of SRD II may be significantly greater if the emerging engagement duties can be enforced efficiently.

\section{ENFORCEMENT OF SHAREHOLDER DUTIES}

If we assume that neither shareholders in general nor institutional investors more specifically have strong incentives to take on a more prominent role in corporate governance and serve wider public interests, then a transformation of corporate governance in a more sustainable direction relies on whether or not the new disclosure duties can be efficiently enforced in a way that promotes the legislation's intentions. ${ }^{69}$

As cited above, Article 3g states that Member States must ensure that institutional investors and asset managers either disclose the information required by Article $3 g$ paragraphs 2 and 3, or disclose why they have chosen not to comply with one or more of these requirements. In order to ensure not only the implementation of the provision but also its enforcement, Article $14 \mathrm{~b}$ requires that Member States 'shall lay down the rules on measures and penalties applicable to infringements of national provisions adopted pursuant to this Directive and

67 Ribstein, L. E.: Accountability and Responsibility in Corporate Governance, Notre Dame Law Review, vol. 81, 2006, pp. 1444-5.

68 Others are less sceptical of the effect shareholders may have in relation to advancing stakeholder issues. See Fairfax, L. M.: Making the Corporation Safe for Shareholder Democracy, op. cit. note 49, p. 96.

69 The discussions in this section are based on Section XX of Birkmose, H. S.: Duties Imposed on Specific Shareholders, op. cit. note 22. 
shall take all measures necessary to ensure that they are implemented. ${ }^{70}$ This means that Member States must ensure that institutional investors and asset managers comply with Article 3g's comply or explain requirement. Public disclosure of institutional investors' and asset managers' investment strategies, their engagement policy and their implementation thereof might reduce the information advantage some shareholders have and could enable other company constituents to act upon the disclosed information to safeguard their own interests. ${ }^{71}$ As such, here and in most agency contexts, disclosure is a means to an end: it allows principals to control their agents. Similarly, in relation to market failure, disclosure should enable the market to include the information in the assessment of the potential market impact of various shareholder actions, which ought to ensure a more efficient market.

While institutional investors are likely to comply with the formal disclosure requirements, this in itself might not lead to improved corporate governance in investee companies, or even to more shareholder engagement. Engagement by institutional investors can only have a positive impact on corporate governance if the individual institutional investor chooses to devote the resources needed to adopt and pursue a meaningful engagement policy. ${ }^{72}$ That is, if shareholder engagement is to have an impact beyond private shareholder interests, the engagement policy and actual engagement should reflect the public dimension. None of this is required under SDR II, nor are Member States required to assess the quality of the institutional investors' engagement or the efficacy of the disclosed information. Thus, the disclosure might do nothing more than reflect status quo, which even could be: 'our engagement policy is that we do not engage.' The question then becomes: who can or should ensure that institutional investors deliver more than a box-ticking exercise? If they choose to present a non-engagement policy, who - if anyone - ought to have the authority to compel them both to engage in a meaningful way and disclose their engagement in an equally meaningful way?

In traditional corporate governance disclosure, the market is expected to incorporate the quality and the value of the disclosed corporate governance statements into the price of a listed company's shares: market disappointment

\footnotetext{
70 However, see Konstantinos Sergakis, who warns that the broad working of Article 14b may raise concerns about its applicability across the EU. Legal vs. Social Enforcement of Shareholder Duties, in: Birkmose, H. S.: and Konstantinos Sergakis (eds.): Enforcing Shareholders' Duties, Edward Elgar, 2018, (forthcoming).

71 Armour, J., Hansmann, H., \& Kraakman, R.: Agency Problems, op. cit. note 21, p. $38 \mathrm{f}$.

72 See also the G20/OECD Principles of Corporate Governance, introduction to section 3, 2015 , where it is said that mandatory requirements to engage may be ineffective and could lead to a box-ticking approach.
} 
with the disclosed reports is reflected in a lower market value. Thus, the board of a listed company has an incentive to ensure the quality of its corporate governance reporting. ${ }^{73}$ Applied to SDR II mandated disclosures by institutional investors, it is doubtful that market pressure will sanction poor disclosure practices. First, it is not clear, who 'the market' is. Institutional investors need not be listed on a stock exchange, even though the SRD II preamble states that disclosure could have a positive impact on investor awareness. Moreover, it is not obvious that 'investor awareness' refers to those who invest their resources with institutional investors'. The phrase could equally well be meant to describe minority investors in the same companies. The latter have limited means to put pressure on the institutional investors beyond choosing to disinvest. Even that might not always be possible. Market pressure might also come from the institutional investors' beneficiaries, and the SRD II drafters might expect such pressure, as the preamble states that disclosure should enable ultimate beneficiaries such as future pensioners to optimize their investment decisions. And yet, even when beneficiaries pay attention to their pension fund, etc., they virtually never have the means to put pressure on their institutional agents, ${ }^{74}$ because, as with minority shareholders, they face a massive collective action problem. Dialogue between institutional investors and investee companies is also mentioned in the preamble, and even though the boards in listed companies may have an interest in their investors' preferences, they lack means to put pressure on their institutional investors. Finally, accountability to society is mentioned, but society has been given no rights to sanction beyond the formal enforcement of disclosure. However, interest groups may be able to put some pressure on institutional investors, by 'naming and shaming' those whose engagement they consider inefficient or suboptimal. ${ }^{75}$ The existence and effect of such strategies could be the subject of future empirical research. Relevant theoretical frameworks offer little insight regarding what we might expect.

In short, the enforcement provisions included in SRD II may ensure black-letter disclosure, but there no immediate mechanism for ensuring that legal disclosures advance the underlying aims of the engagement provisions. Howev-

Evidence shows that the mechanism of comply or explain does not function perfectly. See Risk Metrics, Study on Monitoring and Enforcement Practices in Corporate Governance in the Member States, p. 13, 2009.

${ }^{74}$ See Melis, Paape \& Lückerath-Rovers: Enforceability of institutional investors' responsibilities, op. cit. note 61 .

75 Informal enforcement strategies, such as 'naming and shaming', via the disclosure not only of the violations themselves (e.g. public warning) is also available to national authorities enforcing disclosure. See, Sergakis, K., Legal vs. Social Enforcement, op. cit., note 69, (forthcoming). 
er, the absence of acceptable results might lead regulators to intervene later, which places investors in a conundrum familiar in a variety of contexts: a future choice between more engagement and more regulation. ${ }^{76}$

\section{SHAREHOLDER DUTIES AS A DRIVER FOR A SUSTAINABLE TRANSFORMATION?}

As discussed above, the shareholder duties found in SRD II can be seen as part of an emerging corporate governance agenda. Rather than limiting the actions of shareholders, the duties aim to extend shareholder actions, that is, to promote behavior that supports a political agenda. As we see it, shareholder duties can be part of a transformation of corporate governance practices in either of two ways: the transformation could be initiated by the company, whereby the board of directors proactively includes public interests even in situations where these are not aligned with the shareholder (short-term) interest in creating wealth; or it could be initiated by shareholders who use their shareholder rights to urge corporate behavior that is consistent with public interests, most especially as related to long-term sustainability.

Shareholders were not the only possible target of legislation intended to transform company practices in a more sustainable direction. It might have been more natural to look at the board of directors, which has the power to make most corporate decisions.$^{77}$ Looking forward, legislators might still do so. If, in the future, they impose duties on the board to include certain public interests in their decisions, then shareholders could use their rights to monitor the performance of the board of directors, in particular if management has to report on compliance. But unless new legislative initiatives clearly describe the board of directors' duties in that respect, it seems unlikely that shareholders will use their rights to push for a transformation that serves public interests which are not clearly aligned with their private interests.

Returning to Article 3, institutional investors' engagement policies are expected to explain how they 'monitor investee companies on relevant matters, including strategy, financial and non-financial performance and risk, capital structure, social and environmental impact and corporate governance'. However, the obligations the board of directors assumes regarding the social and

\footnotetext{
76 Melis, Paape \& Lückerath-Rovers: Enforceability of institutional investors' responsibilities, op. cit. note 61 .

77 The limits to managements' right to decide differ among individual Member States. See for instance Andenas, M. \& Wooldridge, F.: European Comparative Company Law, Cambridge, 2009, Chapter 6; or Van Hulle, K. \& Gesell, H. (eds.), European Corporate Law, Nomos, 2006.
} 
environmental impact of the company they manage may depend on hard law as well as soft law, so a new duty of institutional investors to include such perspectives in their control practices might not result in improved practices on the matter,. Moreover, it has been shown in a US context, that even when duties are imposed on the board of directors, shareholder engagement might not be an efficient way to secure a change in practices. $^{78}$

As an alternative to imposing duties on the board of directors, shareholders could take on a responsibility beyond the agency relationship between the board of directors and shareholders and include public interests in their own proactive agenda. However, the role of shareholders in corporate governance is formally limited to the general meeting, which may limit the shareholders' room for maneuver. Their authority at the general meeting depends primarily on the rights they are given in company law. Arguably, these rights first and foremost enable shareholders to monitor the board of directors and to protect their interests in the company. Whether or not shareholders are able to initiate any transformation of company practices depends on the rights given under national company law. In some Member States, shareholder rights are restricted to monitoring the board of directors, while in other jurisdictions shareholders may initiate transformations and obligate the board to carry out decisions taken at the general meeting. ${ }^{79}$ But even if shareholders are able to initiate changes, shareholder-initiated transformations can be expected to take place in only a few situations. Shareholders can be expected to use the rights they are given primarily to protect their interests in the company, and a transformation is unlikely to take place unless the public aim is aligned with shareholder interests.

Finally, legislators may choose to impose duties on shareholders intended to transform company practices in a more sustainable direction. However, a process that is politically driven from above and crafted without adequate sensitivity to countervailing institutional incentives might not have the desired effect. Moreover, any legislative initiatives that require shareholders to be proactive should be within the limits of their authority at the general meetings, and the power to manage the company should remain with the board of directors. ${ }^{80}$

78 Fisch, J. E., The Mess at Morgan, op. cit. note 53, pp. 669 ff., in relation to the advisory shareholder vote on say-on-pay in the US, which was enacted with the Dodd-Frank Act.

79 See Hansen, J. L.: The Role of Shareholders in Public Companies in the Nordic Countries, pp. 83 ff. and Kersting, C.: The Role of Shareholders in Public Companies in Germany, pp. 112 ff., both in: Fleischer, H., Hansen, J. L. \& Ringe, W-G (eds.): German and Nordic Perspectives on Company Law and Capital Markets Law, Tübingen 2015. See also Lekvall, P. (ed.): The Nordic Corporate Governance Model, Stockholm, 2014, pp. 58 ff.

80 See Lekvall, ibid, pp. $69 \mathrm{ff}$. 
While legislators have the power to impose duties on shareholders to promote a desired practice by shareholders, the discussion above on the expected effect of the SRD II shows that the imposition of these new duties might not be sufficient to secure the desired transformation. Outside the agency relationships in companies, it is important that the model regulators choose is backed by efficient enforcement, as shareholders lack sufficient incentives to fulfill their engagement duties without proper enforcement. This feature is lacking in the SRD II disclosure model, as discussed above.

Consequently, if shareholder duties are to become an effective means to secure a desired transformation of corporate governance, we need to consider whether private or public enforcement is preferred. When we move outside the agency relationship, it is essential that legislators identify groups that already have an incentive to enforce shareholder duties, and provide these groups with appropriate means to do so. If we rely on private enforcement, then we have to consider who will benefit the most from compliance and is therefore willing to carry the costs connected with enforcement. Public enforcement may also be an option, giving for instance national financial supervisory authorities the power to enforce and sanction non-compliance. ${ }^{81}$ While the sanctions may differ depending on whether the duties are to be enforced by private parties (for instance by taking the non-compliant shareholders to court) or public parties (using pecuniary or criminal sanctions), it is a fundamental prerequisite that the duties imposed on shareholders are clear and unambiguous, in order for the enforcing party to be able to assess whether or not the shareholders have complied. Moreover, it is essential that the shareholders know what to do to be in compliance with the given duties.

Besides the enforcement issue, the scope of any additional shareholder duties should be considered carefully. If new duties are imposed on shareholders in order to promote a political agenda that does not originate in agency relations or market failure concerns, a number of questions should be carefully considered. For one, as mentioned above in Section 4, it is questionable whether 'third party interests' are best protected by shareholder duties, as shareholder interests cannot be expected always to be aligned with the interests of other company constituents or the wider public. If legislators find that efficiently enforced duties can improve the alignment of shareholder interests with other parties' interests, then legislators need also to consider the costs that shareholders have to carry when such duties are imposed on them. ${ }^{82}$ Furthermore, the costs need to be balanced against the interests the duties are intended to

\footnotetext{
81 See Konstantinos Sergakis, who warns against legal sanctions of the emerging engagement duties in: Legal vs. Social Enforcement, op. cit., note 69, (forthcoming).

82 See Melis, Paape \& Lückerath-Rovers: Enforceability of institutional investors' responsibilities, op. cit. note 61 .
} 
serve, and it must be assessed whether the duties are suited to protect the politically defined interests and whether the need to protect these interests are of greater value than the costs imposed on the shareholders. Legislators need also consider whether duties should be imposed on all shareholders, or a subset of shareholders. If the latter, legislators need to consider whether shareholders of certain types, such as institutional investors, should be imposed duties, or if a universal criterion like shareholding size should trigger the duties. ${ }^{83}$ Finally, legislators need to consider whether duties should be imposed on shareholders in all types of companies or only on shareholders that invest in larger companies or in listed companies.

\section{CONCLUSIONS}

Imposing duties on shareholders can be seen as a transformative intervention in the private ordering of parties in a company. While such a legislative intervention might serve purposes traditionally seen as legitimate, such as protecting the interests of the principal in an agency relationship or ensuring market efficiency in case of concerns of market failure, duties can also serve other aims and SRD II explicitly does so. Duties like those mandated in SRD II are intended to be vehicles that support non-market-driven transformations of corporate governance. This is why legislators turn to other means to promote such transformations. Moreover, legislators may push for a transformation that is intended to serve a wider aim than to protect the interests of the shareholder, including public interests. SRD II has been discussed as an example of legislative attempts to promote a specific corporate governance agenda by the use of duties. In this article, I have argued that, in practice, SRD II duties might not bring about any significant changes to the institutional investors' engagement practices, partly due to an inefficient enforcement mechanism. If shareholder duties are to serve as a vehicle for a sustainable transformation of governance practices, legislators have to consider not only how to enforce the duties efficiently, but also whether this purpose truly justifies their intervention in companies' private ordering.

While shareholder duties can serve as a vehicle for transformation of company law and corporate governance in certain situations, the effect of shareholder duties arguably has clear limits. Therefore, should legislators decide to proceed down the path they started upon with SRD II, they should consider carefully in which situations shareholders duties will have the desired effect.

83 A number of the corporate governance duties we find in company law and capital market law depend on size, as large shareholders have to potential to exercise influence over a company, see Sørensen, K. E.: Shareholders' Duty to Disclose, op. cit. note 31, pp. $311 \mathrm{ff}$. 


\section{LITERATURE}

1. Andenas, M. \& Wooldridge, F.: European Comparative Company Law, Cambridge, 2009.

- DOI: https://doi.org/10.1017/CBO9780511770494

2. Armour, J., Hansmann, H., \& Kraakman, R.: Agency Problems and Legal Strategies, in: Kraakman, R., Armour, J., Davies, P., Enriques, L., Hansmann, H., Hertig, G., Hopt, K., Kanda, H., Pargendler, M., Ringe, W.-G. \& Rock, E. (eds), The Anatomy of Corporate Law. A Comparative and Functional Approach, Oxford, 2017

- DOI: https://doi.org/10.1093/acprof:oso/9780198739630.003.0002

3. Armour, J., Hansmann, H., Kraakman, R. \& Pargendler, M., What Is Corporate Law?, in: Kraakman, R., Armour, J., Davies, P., Enriques, L., Hansmann, H., Hertig, G., Hopt, K., Kanda, H., Pargendler, M., Ringe, W.-G. \& Rock, E. (eds), The Anatomy of Corporate Law. A Comparative and Functional Approach, Oxford, 2017

- DOI: https://doi.org/10.1093/acprof:oso/9780198739630.003.0001

4. Barker, R. M. \& Chiu, I. H.-Y.: Corporate Governance and Investment Management, London, 2017

- DOI: https://doi.org/10.4337/9781784713522

5. Bird, H.: A Critique of the Proprietary Nature of Share Rights in Australian Public Listed Corporations, Melbourne University Law Review, vol. 22, 1998

6. Birkmose, H. S.: Duties Imposed on Specific Shareholders Only, and Enforcement Implications, in: Birkmose, H. S. \& Sergakis, K. (eds): Enforcing Shareholders' Duties, Cheltenham, 2019 (forthcoming).

7. Birkmose, H. S.: European Challenges for Institutional Investor Engagement - is mandatory disclosure the way forward? European Company and Finance Law Review, vol. 112014

8. Birkmose, H. S.: Forcing Shareholder Engagement: Theoretical Underpinning and Political Ambitions, European Business Law Review, vol. 29(4), 2018

9. Birkmose, H. S.: The transformation of passive institutional investors to active owners - mission impossible? in: Birkmose, H. S. Neville, M. \& Sørensen, K. E. (eds), The European Financial Market in Transition, Alphen aan den Rijn, 2011

- DOI: https://doi.org/10.2139/ssrn.1869818

10. Birkmose, H. S. and Möslein, F.: Introduction: Mapping shareholders' duties, in: Birkmose, H. S. (ed.), Shareholders' Duties, Alphen aan den Rijn, 2017

11. Cahn, A.: The Shareholders' Fiduciary Duty in German Company Law, in: Birkmose, H. S. (ed.), Shareholders' Duties, Alphen aan den Rijn, 2017

12. Chiu, I. H.-Y.: The Meaning of Share Ownership and The Governance Role of Shareholder Activism in The United Kingdom, Richmond Journal of Global Law \& Business, vol. 8, 2008-2009 
13. Chiu, I. H.-Y. \& Katelouzou, D.: From Shareholder Stewardship to Shareholder Duties: Is the Time Ripe?, in: Birkmose, H. S.: (ed.), Shareholders' Duties, Alphen aan den Rijn, 2017

14. Fama, E. \& Jensen, M.: Separation of Ownership and Control, Journal of Law and Economics, vol. 26(2), 1983

- DOI: https://doi.org/10.1086/467037

15. Fairfax, L. M.: Making the Corporation Safe for Shareholder Democracy, Ohio State law Journal, vol. 692008

16. Fisch, J. E., The Mess at Morgan: Risk, Incentives and Shareholder Empowerment, University of Cincinnati Law Review, vol. 83, 2014

17. Davies, P. L.: Gower's Principles of Modern Company Law, London, 2001

18. Deakin, S.: The Corporation as Commons: Rethinking Property Rights, Governance and Sustainability in the Business Enterprise, Queen's Law Journal, vol. 37, 2012

19. Demsetz, H.: Toward a Theory of Property Rights, American Economic Review, vol. 57(2), 1967

20. Hansen, J. L.: The Role of Shareholders in Public Companies in the Nordic Countries, in: Fleischer, H., Hansen, J. L. \& Ringe, W-G (eds): German and Nordic Perspectives on Company Law and Capital Markets Law, Tübingen, 2015

21. Hawley, J. P., Hoepner, A. G. F., Johnson, K. J., Sandberg, J. \& Waitzer, E. J. (eds): Cambridge Handbook of Institutional Investment and Fiduciary Duty, Cambridge, 2014

- DOI: https://doi.org/10.1017/CBO9781139565516

22. Hertig, G.: Governance by Institutional Investors in a Stakeholder World, in: Gordon, J. N. \& Ringe, W.-G., The Oxford Handbook of Corporate Law and Governance, Oxford, 2018

23. Hill, J. G., Images of the shareholder - shareholder power and shareholder powerlessness, in Hill, J. G. \& Thomas, R. S. (eds), Research Handbook on Shareholder Power, London, 2015

- DOI: https://doi.org/10.4337/9781782546856.00010

24. Ireland, P., Company Law and the Myth of Shareholder Ownership, Modern Law Review, vol. 62(1), 1999

- DOI: https://doi.org/10.1111/1468-2230.00190

25. Jensen, M. C. \& Meckling, W. H., Theory of the Firm: Managerial Behavior, Agency Costs and Ownership Structure, Journal of Financial Economics, vol. 3(4), 1976

- DOI: https://doi.org/10.1016/0304-405X(76)90026-X

26. Kersting, C., The Role of Shareholders in Public Companies in Germany, in: Fleischer, H., Hansen, J. L. \& Ringe, W.-G. (eds), German and Nordic Perspectives on Company Law and Capital Markets Law, Tübingen, 2015. 
27. Lekvall, P. (ed.), The Nordic Corporate Governance Model, Stockholm, 2014

28. Melis, D., Paape, L. \& Lückerath-Rovers M., Enforceability of institutional investors' responsibilities in corporate governance through the Dutch Corporate Governance Code: are regulators and practitioners on the same page (and to who are institutional investors accountable)? Working Paper 2017

29. Pennington, R., Company Law, London, 2001

30. Ribstein, L. E., Accountability and Responsibility in Corporate Governance, Notre Dame Law Review, vol. 81, 2006

31. Rock, E. B., Institutional Investors in Corporate Governance, in Gordon, J. N. \& Ringe, W.-G.: The Oxford Handbook of Corporate Law and Governance, 2018

32. Sergakis, K., Legal vs Social Enforcement of Shareholder Duties, in: Birkmose, H. S. and Sergakis K. (eds), Enforcing Shareholders' Duties, Cheltenham, 2019, (forthcoming).

33. Stein, P \& Shand, J., Legal Values in Western Society, New York, 1974

34. Sørensen, K.E., Duty of loyalty for shareholders - a possible remedy for conflicts in SME's, in: Neville, M. \& Sørensen, K. E. (eds), Company Law and SMEs, Copenhagen, 2009

35. Sørensen, K. E., Shareholders' Duty to Disclose, in: Birkmose, H. S. (ed.), Shareholders' Duties, Alphen aan den Rijn, 2017

36. Van Hulle, K. \& Gesell, H. (eds), European Corporate Law, Baden-Baden, 2006

37. Worthington, S., Shares and Shareholders: Property, Power and Entitlement: Part 1, Company Lawyer, vol. 22(9), 2001

38. Youngdahl, J., The basis of ficuciary duty in investment in the United States, in Hawley, J. P., Hoepner, A. G. F., Johnson, K. J., Sandberg, J. \& Waitzer, E. J. (eds), Cambridge Handbook of Institutional Investment and Fiduciary Duty, Cambridge, 2014

- DOI: https://doi.org/10.1017/CBO9781139565516.005

\section{THE EUROPEAN COMMISSION DOCUMENTS}

1. Communication From the Commission, Europe 2020, A strategy for smart, sustainable and inclusive growth, $\operatorname{COM(2010)} 2020$ final

2. Communication From The Commission to The European Parliament, The European Council, The Council, The European Central Bank, The European Economic and Social Committee and The Committee of The Regions. Action Plan: Financing Sustainable Growth, COM(2018) 97 final

3. Corporate Governance in Financial Institutions and Remuneration Policies, Green Paper, (COM(2010) 284 final) 
4. EU Corporate Governance Framework, Green Paper, (COM(2011) 164 final)

5. European Company Law and Corporate Governance - A modern legal framework for more engaged shareholders and sustainable companies, (COM(2012) 740 final

\section{REPORTS}

1. Risk Metrics, Study on Monitoring and Enforcement Practices in Corporate Governance in the Member States, 2009. 